\title{
Draf Undang-Undang Perkawinan Indonesia: Basis Filosofis dan Implikasinya dalam Butir-Butir UU
}

\author{
Khoiruddin Nasution
}

As can be seen from the draft of the Law of Marriage (RUU Perkawinan), some new ideas of marital aspects have been included in its chapters and articles. However, in some areas, more critical suggestions are still needed to make the draft more relevant with the social dynamics. This article tries to analyze three aspects of the draft, polygamy, status and authority of spouses, and the last, problems relate divorce. Further, the article also gives the solution for those areas.

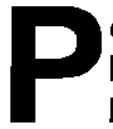

erkawinan adalah terjemahan dari kata Arab zawaja dan nakaha. Kedua kata inilah yang digunakan alQur'an untuk menunjukkan perkawinan antara manusia (Muslim). Kata nakah\}a berarti menghimpun. Sedangkan kata zawaja berarti pasangan. Dengan demikian, dari sisi bahasa perkawinan berarti berhimpunnya dua insan (orang) yang semula sendiri-sendiri menjadi satu kesatuan. Dengan penyatuan ini berarti, yang semula mereka adalah dua bagian yang terpisah; kemudian dengan perkawinan mereka menjadi satu kesatuan yang utuh dan saling melengkapi, yang disebut pasangan (zauj dan zaujah).

Pertanyaannya kemudian adalah, kenapa kedua insan ini harus berhimpun menjadi satu kesatuan lewat perkawinan (akad nikah) yang disebut dengan keluarga (rumah tangga)? Pertanyaan ini secara prinsip sama dengan pertanyaan apa yang menjadi dasar filosofis perkawinan. Jawaban terhadap pertanyaan ini dapat ditemukan salah satunya - dengan mengkaji tujuan, yang oleh sebagian ilmuwan menyebutnya fungsi atau hikmah perkawinan.' Secara prinsip indikator tujuan, 'illat (rasio logis), hikmah, atau fungsi inilah yang dijadikan para ahli sebagai ukuran untuk menemukan nilai filosofis dari satu tindakan / aturan (norma) hukum, termasuk di dalamnya tindakan (norma) perkawinan. Selanjutnya, untuk mencapai tujuan tersebut menurut hemat penulis diperlukan sejumlah prinsip. Prinsip-prinsip tersebut melekat pada tujuan dan sekaligus menjadi unsur penting untuk memahami dasar filosofis perkawinan dimaksud. Karena itu, tujuan dan prinsip perkawinan adalah satu kesatuan yang tidak terpisahkan untuk menemukan dasar filosofis perkawinan. Tulisan ini merupakan hasil penelitian tentang tujuan perkawinan. Harapannya adalah, bahwa tulisan ini dapat menjadi salah satu sumbang pikir sebagai bagian dari dasar filosofis draft UndangUndang Perkawinan Indonesia. Dasar filosofis ini diharapkan pula menjadi

\footnotetext{
1 Mengingat tujuan, hikmah, 'illaf (rasio logis) atau fungsi perkawinan secara prinsip adalah sama, maka dengan menulis tujuan dalam tulisan ini dimaksudkan juga fungsi, 'illat atau hikmah.
} 
landasan butir-butir yang ada dalam Batang Tubuh Undang-Undang.

Karena itu, sistematika tulisan ini adalah, setelah pendahuluan di bagian pertama, dilanjutkan dengan pembahasan tentang tujuan perkawinan pada bagian kedua. Bagian ketiga dengan sub judul, 'Implikasi dalam Butir-Butir Undang-Undang', diuraikan analisis singkat terhadap butir-butir draft Undang-Undang. Kemudian dipungkasi dengan kesimpulan pada bagian akhir.

\section{Tujuan Perkawinan}

Adapun tujuan perkawinan yang umum dicatat para ahli adalah untuk terciptanya rumah tangga (keluarga) yang penuh kedamaian, ketenteraman, cinta dan kasih sayang (sakinah, mawaddah dan rahmah). Ada yang mengungkapkan, tujuan perkawinan disyari'atkan - bukan dengan jalan free sex dan semacamnya - adalah untuk hidup berdampingan antara pasangan, dengan penuh cinta dan kasih sayang, damai dan sejahtera. Hal ini seperti diungkapkan dengan tegas dalam al-Rum (30):21:

$$
\begin{aligned}
& \text { ومن ايداته أن خلق لكم من أنفسكم أزواجا }
\end{aligned}
$$

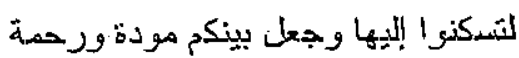

$$
\begin{aligned}
& \text {. إن في ذلك لآيات لقوم يثذكرون }
\end{aligned}
$$

Dan di antara tanda-tanda kekuasaanNya ialah Dia menciptakan untukmu isteri-isteri darijenismu sendiri, supaya kamu cenderung dan merasa tenteram kepadanya, dan dijadikan-Nya di antaramu rasa kasih dan sayang. Sesungguhnya pada yang demikian itu benar-benarterdapat tanda-tanda bagi kaum yang berpikir.

Tujuan ini diakui oleh hampir semua ulama. Karena itu, tujuan ini disebut tujuan pokok.
Di samping itu, menurut analisis sejumlah ulama masih ada sejumlah tujuan lain, yang oleh al-Ghazâlî disebut fungsi perkawinan, sementara al-Jurjâwî menyebutnya hikmah perkawinan. Menurut al-Ghazâlî ada minimal lima fungsi perkawinan, yakni: (1) memperoleh keturunan, (2) menjaga diri dari godaan setan, (3) menenangkan dan menenteram-kan jiwa, (4) membagi tugas rumah tangga, dan (5) arena berlatih untuk bertanggung jawab. ${ }^{2}$ Sementara menurut alJurjâwî, hikmah perkawinan ada tiga: (1) sarana reproduksi untuk meneruskan atau melanjutkan kehidupan umat manusia di muka bumi, (2) memenuhi watak dasar manusia - mungkin maskudnya adalah untuk memenuhi kebutuhan biologis - dan (3) menjamin hak-hak kewarisan. ${ }^{3}$ Tanpa bermaksud menafikan teori-teori tersebut, kalau dicermati sejumlah nash yang berbicara tentang perkawinan, dapat dicatat minimal lima tujuan, yakni: (1) tujuan reproduksi, (2) tujuan pemenuhan kebutuhan bilogis, (3) memperoleh ketenangan, (4) menjaga kehormatan, dan (5) tujuan ibadah. Kelima tujuan ini pula yang dibahas berikut ini.

Kaitannya dengan tujuan pertama, tujuan reproduksi, ada sejumlah nash, ayat al-Qur'an dan sunnah $\mathrm{Nabi}$ yang mengisyaratkan tujuan pengembangbiakan umat manusia atau mempertahankan/ meneruskan generasi (reproduksi) di bumi. Misalnya dalam surah al-Shûrâ (42):11:

2 Abû Hâmid al-Ghazâlî, $I$ hyyâ' 'Ulum al-Dîn (Beirût: Dâr al-Fikr, 1975), IV: 102-114.

3 'Alî al-Jurjâwî, Hikmatu al-Tasyrí' wa Falsafatuh (Beirût: Dâr al-Fikr, 1994), Il: 4-5. 
Topik: Draf Undang-undang Perkawinan Indonesia..., Khoiruddin Nasution

$$
\begin{aligned}
& \text { فاطر السمو ات والأرض جعل لكم نن } \\
& \text { أنفسكم أزرواجا ومن الأنعام أزوراجا } \\
& \text { يذروكم فيه ليس كمنكه شيء و هو التسميع } \\
& \text { البصيز }
\end{aligned}
$$

“(Dia) Pencipta langit dan bumi. Dia menjadikan bagi kamu darijenis kamu sendiri pasangan-pasangan dan dari jenis binatang ternak pasanganpasangan (pula), dijadikan-Nya kamu berkembang biak dengan jalan itu. Tidak ada sesuatupun yang serupa dengan Dia, dan Dia-lah Yang Maha Pendengar lagi Maha Melihat".

Kedua, dalamal-Nahl (16):72:

$$
\begin{aligned}
& \text { و الله جعل لكم من أنفسكم أزو اجا وجعل } \\
& \text { لكم هن أزو اجكم بنين وحفدة ورزقكم من } \\
& \text { الطبيدات }
\end{aligned}
$$

"Allah menjadikan bagi kamu isteriiseri dari jenis kamu sendiri dan menjadikan bagimu dari isteri-isteri kamu itu anak-anak dan cucu-cucu, dan memberimu rezeki dari yang baikbaik..."

Ketiga, dalam al-Nisâ' (4):1:

$$
\begin{aligned}
& \text { ياليها الناس اتقوا ربكم الذي خلقكم من } \\
& \text { نفس واحدة وخلق مذها زوجها وبث } \\
& \text { مذهما رجالا كثير ا ونساء }
\end{aligned}
$$

"Hai sekalian manusia! bertakwalah kepada Tuhan-mu yang telah menciptakan kamu dari seorang diri, dan dari padanya Allah menciptakan isterinya, dan dari pada keduanya Allah memperkembangbiakan laki-laki dan perempuan yang banyak".

Ayat-ayat al-Qur'an di atas ditambah dengan sejumlah sunnah Nabi Muhammad SAW., di antaranya adalah:

$$
\begin{aligned}
& \text { تزوجو اللودودالولود فاني مكاثز بكم الامم } \\
& \text { يوم القيامة }
\end{aligned}
$$

nikahlah dengan pasangan yang subur (produktif), sebab aku bangga kalau nantijumlah umatku demikian banyak di hari kiamat

Teks lain dengan maksud yang sama disebutkan:

$$
\begin{aligned}
& \text { تناكحو ا تكاثرو فاني اباهي بكم الامم يوم } \\
& \text { القيامة لدامت }
\end{aligned}
$$

Nikahlah kamu! dengan itu jumlah kamu menjadi banyak, sebab aku bangga dengan jumlah umat yang banyak kelak di hari kiamat

Semua nash (al-Qur'an dan sunnah Nabi) di atas menunjukkan tujuan pentingnya reproduksi agar umat Islam kelak di kemudian hari menjadi umat yang banyak,baik secara kuantitas maupun kualitas. Dengan kata lain, dari nash-nash tersebut di atas terlihat adanya kebutuhan untuk mempertahankan atau meneruskan generasi.

Tentang pentingnya umat yang berkualitas diisyaratkan dalam surah alNisa' (4):9:

$$
\begin{aligned}
& \text { وليخش الذين لو تركوا من خلفهم ذرية } \\
& \text { ضعاقا خافو! عليهم فليتقو الله وليقولوا } \\
& \text { قو لا سدبيدا }
\end{aligned}
$$


yang lemah, yang mereka khawatir terhadap (kesejahteraan) mereka. Oleh sebab itu hendaklah mereka bertakwa kepada Allah dan hendaklah mereka mengucapkan perkataan yang benar.

Karena itu, Nabi mengajak untuk hidup berkeluarga dan menurunkan serta mengasuh anak-anak mereka menjadi warga umat Islam yang saleh. Beliau juga memuji pasangan yang bisa memberikan anak. Sebab anak akan mengembangkan Islam di segala zaman.

Kaitannya dengan tujuan kedua, pemenuhan kebutuhan seksual, dapat dilihat dalam surah al-Baqarah (2):187:

$$
\begin{aligned}
& \text { الحل لكم ليلة الصيام الترفث إلى نسانكم هن } \\
& \text { لباس لكم وأنثم لباس لهن علم الل أنكم كنتم }
\end{aligned}
$$

ثختانون أنفسكم فتاب عليكم و عفا عذكم لئم

Dihalalkan bagikamu pada malam hari puasa bercampur dengan isteri-isteri kamu, mereka itu adalah pakaian bagimu, dan kamu pun adalah pakaian bagi mereka. Allah mengetahui bahwasanya kamu tidak dapat menahan nafsumu, karena itu Allah mengampunikamu dan memberima'af kepadamu....

Kedua, dalam surah al-Baqarah (2):223:

نساؤكم حرث لكم فأتو ا حرثكم أنى شنتم

Isteri-isterimu adalah (seperti) tanah tempat kamu bercocok-tanam, maka datangilah tanah tempat bercocoktanammu itu bagaimana saja kamu kehendaki.
Ketiga, dalam surah al-Nûr (24):33:

$$
\begin{aligned}
& \text { وليستعفف الذين لا يجدون نكاحا حتى } \\
& \text { يغنيهم الله من فضله و الذين ييتخون الكنتاب } \\
& \text { مما ملكت أيمانكم فكاتبو هم إن علمتم فيهم } \\
& \text { خيرا و اتو هم من هال الله الذي اتكاكم ولا } \\
& \text { تكر هو ا فتياتكم على البغاء إن أردن } \\
& \text { تحصنا لتبتغو ا عرض الحياة الدنيا ومن } \\
& \text { يكرهن فإن الله هن بعد إكراههن غفور } \\
& \text { رحيم }
\end{aligned}
$$

"Dan orang-orang yang tidak mampu kawin hendaklah menjaga kesucian (diri) nya, sehingga Allah memampukan mereka dengan karunia-Nya. Dan budak-budak yang kamu miliki yang menginginkan perjanjian, hendaklah kamu buat perjanjian dengan mereka, jika kamu mengetahui ada kebaikan pada mereka, dan berikanlah kepada mereka sebagian dari harta Allah yang dikaruniakan-Nya kepadamu. Dan janganlah kamu paksa budak-budak wanitamu untuk melakukan pelacuran, sedang mereka sendiri menginginkan kesucian, karena kamu hendak mencari keuntungan duniawi. Dan barangsiapa yang memaksa mereka, maka sesungguhnya Allah adalah Maha Pengampun lagi Maha Penyayang (kepada mereka) sesudah mereka dipaksa (itu)". 
Keempat, surah al-Ma‘ârij (70):29-31:

$$
\begin{aligned}
& \text { والنين هم لفروجهم حافظون(9 ؟) إلا على } \\
& \text { أزواجهم أو ما ملكت أيمانهم فإنهم غير } \\
& \text { ملومين }
\end{aligned}
$$

Dan orang-orang yang memelihara kemaluannya, kecuali terhadap isteriisteri mereka atau budak-budak yang mereka miliki, maka sesungguhnya mereka dalam hal ini tidak tercela. Barangsiapa mencari yang di balik itu, maka mereka itulah orang-orang yang melampaui batas.

Kelima, dalam al-Mu'minûn (23):5-7:

$$
\begin{aligned}
& \text { و الذين هم لفروجهم حافظون(0) إلا على إنى } \\
& \text { أزو اجهم او ما ملكت أيماذهم فإنهم غيرن }
\end{aligned}
$$

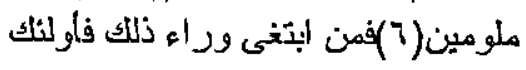

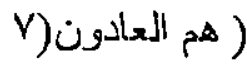

"Dan orang-orang yang memelihara kemaluannya, kecuali terhadap isteriisteri mereka atau budak-budak yang mereka miliki, maka sesungguhnya mereka dalam hal ini tidak tercela. Barangsiapa mencariyang dibalik itu, maka mereka itulah orang-orang yang melampaui batas".

Adapun konteks dari al-Baqarah (2):223, isteri dianalogkan dengan kebun untuk bercocok tanam, adalah menggambarkan kondisi Arab yang memang sangat jarang ditemukan kebun untuk bercocok tanam. Sebab Arab terkenal sebagai daerah tandus yang kurang baik untuk digunakan bercocok tanam. Karena itu, metafor al-Qur'an menggunakan kebun untuk menunjukkan isteri, dimaksudkan agar isteri dijaga dan dirawat dengan baik dan penuh pengertian, perhatian, cinta dan kasih sayang, kira-kira seperti merawat bunga di musim kering. Kalau tidak dirawat dan disirami dengan baik bisa jadi kebun tersebut akan mati kekeringan.

Hal kedua yang perlu mendapat perhatian kaitannya dengan tujuan pemenuhan kebutuhan biologis (seksual) adalah, bahwa pemenuhan kebutuhan ini menjadi hak bersama suami dan isteri. Bukan hak isteri saja, bukan juga hak suami saja, tetapi kedua-duanya. Karena itu, kalau hanya salah satu pihak (pasangan) yang mendapat kepuasan alias terpenuhi kebutuhan bilogisnya sementara pihak (pasangan) yang satu tidak mendapat, sama artinya dengan terjadi pelanggaran hak antara pasangan. Karena itu, amat tepat apa yang dirumuskan sebagian ulama fikih, bahwa salah satu hak dan sekaligus kewajiban bersama (saling) antara suami dan isteri adalah memenuhi kebutuhan biologis pasangannya. ${ }^{4}$ Dengan ungkapan yang lebih abstrak, tetapi untuk menunjukkan maksud dan tujuan yang sama, disebutkan ibnu Qudâmah dari mazhab Hanbali, bahwa pasangan saling wajib mempergauli pasangannya dengan baik. $^{5}$

Tujuan ketiga, memperoleh ketenangan (مونة) (سكينة), cinta dan kasih sayang (j). Ayat yang sangat tegas menyebutkan tujuan ini adalah dalam surah al-Rûm (30):21, seperti dicatat sebelumnya. ${ }^{6}$

${ }^{4}$ al-Imâm 'Alâu al-Dîn Abî Bakar bin Mas'ûd a'-Kâsânî, Kitâb Badâi'u al-Sanâi'u fi Tartíb alShârâi', cet. 1 (Beirût: Dâr al-Firk, 1417/1996), Il: 489-490.

${ }^{5}$ Muwaffaqu al-Dîn Abî Muhammad 'Abd Allâh bin Ahmad ibn Qudâmah, al-Mughnî wa al-Sharh) al-Kabîr, edisi 1 (Beirût: Dâr al-Fikr, 1404/1984), IX: 282-283.

6 “Dan diantara kekuasanNya ialah Dia menciptakan untukmu isteri-isteri dari jenismu sendiri, supaya kamu cenderung dan merasa 
سكينة berasal dari kata سكن yang berarti tenang atau diamnya sesuatu setelah bergejolak. Maka perkawinan adalah pertemuan antara pria dan wanita, yang kemudian menjadikan (beralih) kerisauan antara keduanya menjadi ketenteraman atau sakinah menurut bahasa al-Qur'an (al-Rûm (30):21). Maka penyebutan سكين untuk pisau adalah karena pisau itu alat sembelih yang menjadikan binatang yang disembelih tenang. ${ }^{7}$

Sejalan dengan tujuan memperolah ketenangan, bersumber dari al-Rûm (30):21, ditambah dengan beberapa ayat lain, juga menunjukkan bahwa hubungan suami dan isteri adalah hubungan cinta dan kasih sayang. Misalnya al-Qur'an menggambarkan hubungan Adam dan Hawa. Demikian juga diisyaratkan dalam surah alBaqarah (2): 187, bahwa suami dan isteri sebagai pakaian antara keduanya. هن لباس لكم و أنتم لباس لهن

Dari ayat-ayat ini jelas bahwa hubungan suami dan isteri adalah hubungan cinta dan kasih sayang, dan bahwa ikatan perkawinan pada dasarnya tidak dapat dibatasi hanya dengan pelayanan yang bersifat material. Pemenuhan kebutuhan material, seperti makanan, pakaian, tempat tinggal dan lainlainnya, hanya sebagai sarana untuk mencapai kebutuhan yang lebih mulia dan tinggi, yakni kebutuhan rohani, cinta, kasih sayang, dan barakah dari Allah. Dengan demikian asumsinya adalah, bahwa pelayanan yang bersifat material akan diikuti dengan hubungan batin, yakni cinta dan kasih sayang. Dari sisi ini dapat disimpulkan, bahwa ketika al-Qur'an memproklamasikan tidak mungkinnya seorang suami berbuat adil di antara para isterinya, sama artinya dengan menyatakan bahwa tidak mungkin seorang laki-laki mencintai lebih dari seorang wanita sebagai isteri.. ${ }^{8}$ Lagi-lagi harus ditekankan dan perlu mendapat perhatian serius, bahwa ketenangan yang ingin dicapai dalam kehidupan rumah tangga adalah ketenangan berdua/bersama suami dan isteri, bahkan kalau sudah mempunyai anak atau anak-anak, maka termasuk ketenangan anak atau anak-anak, bukan ketenangan salah satu pihak, apalagi kalau ketenangan ini didapatkan di atas penderitaan pasangan. Karena itu, kalau hanya salah satu pihak (pasangan) yang mendapatkan ketenangan sama artinya dengan menyebut belum tercapai tujuan perkawinan.

Tujuan keempat dari perkawinan adalah untuk menjaga kehormatan, yakni kehormatan diri sendiri, anak dan keluarga. Dengan ungkapan lain, dipilihnya perkawinan bagi manusia (Muslim) adalah untuk kehormatan dan martabat manusia itu sendiri. ${ }^{9}$ Tujuan ini tersirat di samping dalam ayat-ayat yang ditulis ketika mengutarakan tujuan pemenuhan kebutuhan biologis (seksual), khususnya al-Nûr (24):33, alMa'ârij (70):29-31, dan al-Mu'minûn (23):57, juga dalam al-Nisâ' (4):23:

tenteram kepadanya, dan dijadikan-Nya diantaramu rasa kasih dan sayang. Sesungguhnya pada yang demikian itu benarbenar terdapat tanda-tanda bagi kaum yang berpikir".

${ }^{7}$ M. Quraish Shihab, Wawasan al-Quran: Tafsir Maudhu'i atas Pelbagai Persoalan Ummat (Bandung: Mizan, 1996), him. 192.

${ }^{8}$ Fazlur Rahman, "The Controversy over The Muslim Family Law," dalam Donald. E. Smith (ed.), South Asian Politics and Religion (Princeton: Princeton University Press, 1966), hlm. 417.

${ }^{9}$ Lihat Abidin dan H. Aminuddin, Figh Munakahat I (Bandung: Pustaka Setia, 1999), hIm. 2. 


$$
\begin{aligned}
& \text { وأحل لكم ما وراء ذلكم أن ثبتَغوا بأمو الكم } \\
& \text { محصنين غير مسافحين فما استمتعتم به } \\
& \text { منهن فاتئ هن أجور هن فريضة ورلا جناح } \\
& \text { عليكم فيما نز اضيتم به من بعد الفريضة } \\
& \text { إن الشه كان عليما حكيما }
\end{aligned}
$$

Dan dihalalkan bagi kamu selain yang demikian (yaitu) mencari isteri-isteri dengan hartamu untuk dikawini bukan untuk berzina. Maka isteri-isteri yang telah kamu nikmati (campuri) di antar mereka, berikanlah kepada mereka mahamya (dengan sempuma), sebagai suatu kewajiban......

Penting pula dijelaskan, bahwa ada sekelompok Muslim yang menjadikan ayat ini sebagai dalil bolehnya nikah mut'ah (nikah sementara dengan cara kontrak), yakni golongan syi'ah. Kelompok ini beralasan, bahwa ayat ini, khususnya potongan فما أستمدتعثم به مذهن menjadi dasar bolehnya nikah mut'ah. Pandangan ini tidak sejalan dengan pesan yang ingin disampaikan dalam ayat ini secara keseluruhan. Bahkan potongan ayat tersebut menjelaskan tentang kewajiban mahar bagi suami yang sudah berhubungan dengan isterinya (sebagai layaknya suami dan isteri).

Nash lain yang menunjukkan tujuan kehormatan dan menjadi martabat manusia itu sendiri adalah hadis Nabi, yang diriwayatkan oleh imam Bukhârî dan imam Muslim, dua imam hadis paling terkenal dan paling diakui kejujurannya (thiqah) juga mencatat berupa perintah untuk menikah bagi para pemuda-pemudi yang sudah sanggup/mampu, yang berbunyi: ${ }^{10}$

$$
\begin{aligned}
& \text { يادعشر الثبابب من السئحلاع منكم الباعة } \\
& \text { فليتزوج فانه اغض بالبصر واحصن } \\
& \text { اللفزج ومن لم يستطع فعليه بالصوم فانه } \\
& \text { له وجاء }
\end{aligned}
$$

Hai para pemuda dan pemudil Siapa di antara kamu yang mempunyai kemampuan, maka nikahlah, sebab nikah itu dapat memejamkan mata, dan memelihara kemaluan, sedang bagi yang belum mempunyai kemampuan menikah agar menunaikan ibadah puasa, sebab puasa dapat menjadi penawarnafsu syahwat Tujuan kelima adalah untuk mengabdi dan beribadah kepada Allah (tujuan ibadah I ta'abbudi). Tujuan ini tersirat dari beberapa nash yang sebelumnya sudah dicatat. Di antara teks nash yang secara langsung menyebut tujuan tersebut adalah sunnah Nabi yang menyatakan:

$$
\text { ومن نزوج فقد الحرز شطر دينه فليتق الش }
$$

10 Hadis ini bersumber dari 'Abdullâh bin 'Umar dalam al-Bukhâri,> Sa\{h\}îh \} al-Bukhârî. "Kitab al-Nikâh\}", hadis no. 4677 dan 4678, "Kitâb al-S\{aum", hadis no. 1772; Abû Dâud, Sunan Abi Dâud, "Kitâb al-Nikâh\}", hadis no. 1750; alTirmidhî, Sunan al-Tirmidhî,, "Kitâb al-Nikâh\}", hadis no. 1001; Ibn Mâjah, Sunan Ibn Mâjah, "Kitâb al-Nikâh\}", hadis no. 1835; al-Nasâ'i, Sunan al-Nasâ $̂$, "Kitâb al-S\{aum", hadis no. 2207, 2208, 2209, 2210 dan 2211, "Kitâb al-Nikâh\}", hadis no. 3155, 3156, 3157, 3158 dan 3159; Ah\}mad, Musnad Ahlmad, hadis no. $3411,3819,3830$, 3903 dan 4050; dan al-Dảrimî, Sunan al-Dârimî, “Kitâb al-Nikâh\}", hadis no. 2071 dan 2072. 
Topik: Reformasi Peran Hukum Islam di Indonesia

seseorang yang melakukan perkawinan sama (dianalogkan) dengan seseorang yang memenuhi setengah agama.

Nash ini sangat jelas dan tegas menyebutkan, bahwa melakukan perkawinan adalah bagian dari melakukan agama. Melakukan perintah dan anjuran agama tentu bagian dari ibadah. Dengan demikian menjadi jelas, bahwa melakukan perkawinan adalah bagian dari ibadah. Nash lain meskipun tidak secara tegas/langsung tetapi makna tersirat, misainya hadis Nabi Muhammad yang mempunyai harapan pribadi, yaitu umatnya akan berjumlah banyak pada akhir zaman nanti, seperti disebutkan dalam satu hadis: ${ }^{11}$

$$
\text { تزوجو اللودودالولمود فاني مكاثر بكم الامم }
$$

nikahlah dengan pasangan yang penuh kasih dan subur (produktif), sebab aku bangga kalau nanti jumlah umatku demikian banyak di hari kiamat

Teks lain dengan maksud yang sama disebutkan:

$$
\text { تاكحو ا تكائرو فاني اباهي بكم الامم يوم }
$$

Nikahlah kamu! Dengan pernikahan jumlah kamu menjadi banyak, sebab aku bangga dengan jumlah umat yang banyak di hari kiamat

Dua hadis terakhir pada prinsipnya (tekstual) menjelaskan tentang tujuan reproduksi dalam perkawinan, yakni untuk meneruskan keturunan (regenerasi) dan memperbanyak umat Muhammad (Muslim). Tetapi dengan mengikuti sunnah Nabi sama artinya dengan melakukan ibadah. Karena itu, menjadi jelas bahwa dengan menjalankan perkawinan sebagai bagian dari melakukan sunnah Nabi Muhammad SAW berarti juga melakukan ibadah.

Hadis lain adalah pengakuan Nabi sendiri: ${ }^{12}$

$$
\text { ونكي وازيوج النساء من رغب و افطر واصلي وارقد عن سنتي فليس }
$$

bahwa saya adalah puasa dan berbuka, solat dan tidur, dan menikahi wanita; 'siapa yang benci sunnahku maka orang tersebut tidak termasuk ummatku'.

Ada satu riwayat dari 'Aîi bin Abî Tâlib, bahwa suatu waktu Rasulullah dan sahabatnya lewat dan mendengar nyanyinyanyian dan permainan di satu perkampungan (bani Zarîq), setelah Nabi konfirmasi kepada sahabat tentang kasus tersebut, ternyata karena ada orang yang sedang melakukan acara perkawinan, Rasul berkomentar, 'orang tersebut sudah menyempurnakan agamanya', dan menambahkan 'jangan melacur dan jangan melakukan pernikahan sirri.

Hadis-hadis ini semakin memperjelas dan mempertegas bahwa melakukan perkawinan adalah bagian dari ibadah. Dengan demikian menjadi semakin jelas pula bahwa di antara tujuan perkawinan

11 Hadis ini bersumber dari Ma'qal bin Yasar, dalam Abú Dâud, Sunan Abî Dâud, "Kitâb alNikâh", hadis no. 1754; at-Nasâî́, Sunanal-Nasâ'T. "Kitâb al-Nikâh", hadis no. 3175 .

${ }^{12}$ Hadis ini bersumber dari Thabit bin Anas, dalam Muslim, Sahih Muslim, "Kitab al-Nikâh", hadis no. 2487; al-Nasâ'i, Sunan al-Nasâ't, "Kitâb al-Nikâh", hadis no. 3165; Ah)mad, Musnad Ahmad, hadis no. 13045, 13230, dan 13534. 
adalah untuk tujuan beribadah kepada Allah SWT.

Sebagai tambahan, meskipun bukan tujuan perkawinan, tetapi dapat disebut dan penting dipahami, bahwa dalam perkawinan bukan hanya urusan murni ibadah (ibadah maqda), tetapi di dalamnya juga ada unsur sosial. Karena itu menjadi tidak tepat kalau ada orang berpendapat bahwa perkwinan hanya murni urusan pribadi (seseorang) dengan Allah, dan tidak perlu campur tangan orang lain dan pemerintah. Sebab sejumlah hadis menunjukkan bahwa dalam perkawinan juga ada unsur sosial kemasyarakatan, yang karenanya penting mendapat perhatian sekaligus penting pula keterlibatan pihak lain, yang boleh jadi adalah pemerintah. hadis:

Misalnya disebutkan dalam sebuah

$$
\text { اعلنو الأنكاح ولو بالدف }
$$

Umumkanlah (iklankan) perkawinan walaupun hanya dengan jalan sekedar pukulan gendang

Teks lain denga maksud yang sama:

$$
\text { اخبرو الأنكاح و اخفو الخطبة }
$$

Umumkanlah perkawinan dan sembunyikanlah pelamaran

Masih untuk tujuan yang sama, dengan teks yang berbeda, disebutkkan, untuk membedakan antara nikah yang dirahasiakan (sirri) dengan nikah non-sirri harus ada alunan suara dan pukul-pukulan', seperti disebutkan dalam sebuah hadis: ${ }^{13}$

$$
\text { و فصل ما بين الدلال و الحز أم بالصوت في النكاح }
$$

Pembeda antara yang halal dengan yang haram (dalam permikahan) adalah dengan adanya alunan suara dan rebana.
Ajaran yang dibawa hadis-hadis tersebut adalah, bahwa perkawinan bukan murni urusan pribadi yang bersifat privat, tetapi di dalamnya ada unsur sosial kemasyarakatan. Itulah yang menjadi salah satu alasan kenapa perkawinan harus diumumkan kepada khalayak ramai. Adapun cara mengumumkan atau memberitahukan kepada masyarakat sesuai dengan kondisi dan keadaan. Tetapi yang pasti adanya usaha merahasiakan perkawinan tidak sejalan dengan prinsip perkawinan. Karena itu, tepat apa yang dirumuskan al-Zuhailî, bahwa pencatatan perkawinan termasuk syarat perkawinan yang harus dipenuhi, sama statusnya dengan kehadiran saksi, wali dan sejenisnya. Sebab pencatatan perkawinan adalah kontekstualisasi dari keharusan mengumumkan perkawinan, sebagaimana yang diajarkan nabi Muhammad. Adapun rukun perkawinan hanyalah akad perkawinan (akad nikah), selainnya hanya syarat. ${ }^{14}$

Dengan ringkas, dari hadis-hadis di atas menjadi jelas bahwa dalam perkawinan ada unsur sosial yang harus dijaga oleh para pasangan. Para pasangan tidak tepat untuk menjustifikasi bahwa urusan pernikahan hanya murni urusan mereka berdua dengan Allah. Tetapi dalam perkawinan harus ada keterlibatan orang lain, termasuk pemerintah.

Untuk menekankan, dari beberapa nash tersebut di atas dapat diringkas, bahwa

${ }^{13}$ Hadis ini bersumber dari Muh\}ammad bin Hâtib, dalam al-Tirmidhî, Sunan al-Timidhî, "Kitâb al-Nikâh\}", hadis no. 1008; al-Nasâ'î, Sunan alNasâ'î, "Kitâb al-Nikâh\}>", hadis no. 3316 dan 3317; Jbn Mâjah, Sunan Ibn Mâjah, "Kitâb alNikâh", hadis no. 1886; Ah\}mad, Musnad Ah)mad, "Músnad al-Kâfiyûn", hadis no. 17563 dan 17564.

${ }^{14}$ Wahbah al-Zuh\}ailî, al-Figh al-Islâm wa Adillatuhu, cet. 3 (Damaskus: Dâr al-Fikr, 1989), VII:62. 
berdasar tujuan pernikahan tersebut mengisyaratkan, bahwa suami dan isteri adalah satu pasangan yang saling membutuhkan dan saling melengkapi, tidak ada pihak yang lebih penting dari yang lain, tidak ada pihak yang lebih tinggi dari yang lain, tidak ada pihak yang lebih mempunyai otoritas dari yang lain. Kedua suami dan isteri harus merasa saling membutuhkan dan saling membantu, kedua suami dan isteri harus saling melengkapi, keduanya harus saling menutupi kekurangan pasangannya dengan kelebihan yang dimiliki.

Karena itu, dengan singkat dapat disebutkan, bahwa perkawinan mempunyai tujuan yang demikian mulia dan sakral, yang secara sederhana dan dalam tujuan pendek disebut untuk menciptakan dan membentuk keluarga (rumah tangga) yang bahagia, damai, tenteram dan kekal. Barangkali karena demikian mulianya perkawinan itulah yang menyebabkan kenapa Islam sangat menghindar dan membenci perceraian (perpisahan). Misalnya disebutkan bahwa kalau pun ada kebencian antara suami dan isteri dalam rumah tangga, mereka tetap dianjurkan agar bersabar, seperti disebutkan dalam surah al-Nisa' (4):19:

$$
\begin{aligned}
& \text { ياليها الذين عامنوا لا بِل لكم أن ترثوا } \\
& \text { النساء كر ها و لا تعضلو هن لتذهبوا } \\
& \text { بعضن ها التيتموهن إلا أن ياتين بفاحشة } \\
& \text { مبينة و عاشتروهن بالمعروف فإن } \\
& \text { كر هئموهن فعسى ان تكر هوا شيئا } \\
& \text { ويجعل الثه فيه خبر اكثيرا }
\end{aligned}
$$

Hai orang-orang yang beriman, tidak halal bagi kamu mempusakai wanita dengan jalan paksa, dan jangalah kamu menyusahkan mereka karena hendak mengambil kembali sebagian dari apa yang telah kamu berikan kepadanya, terkecuali bila mereka melakukan pekerjaan keji yang nyata. Dan bergaullah dengan mereka secara patut. Kemudian bila kamu tidak menyukai mereka (maka bersabarlah) karena mungkin kamu tidak menyukai sesuatu, padahal Allah menjadikan padanya kebaikan yang banyak.

Karena.itu, perceraian mungkin terjadi tetapi hanya dalam kondisi yang sangat terpaksa (darurat), dalam bahasa nash, boleh yang terpaksa / boleh yang dibenci (ابغض الحله).. Adapun pihak yang menentukan (mengukur) apakah yang terbaik bagi pasangan; untuk meneruskan atau mengakhiri hubungan perkawinan (cerai), adalah pihak ketiga yang lebih adil dan obyektif, dalam bahasa nash disebut juru damai (hakam). Hal ini dinyatakan dalam al-Nisa (4):35:

$$
\begin{aligned}
& \text { وإن خفتم شقاق بينهما فابعثوا حكما من } \\
& \text { أهله وحكما من أهلها إن يريدا إصداحدا } \\
& \text { يوفق الله بيذهما إن الله كان عليما } \\
& \text { خبير (ب) }
\end{aligned}
$$

Jika kamu khawatir ada percekcokan /perselisihan antara suami dan isteri, maka kirimlah juru pendamai dari (wakil) keluarga laki-laki (suami) dan dari (wakil) keluarga perempuan (isteri). Jika juru pendamai tersebut bermaksud mengadakan perdamaian, maka Allah akan memberikan taufiq kepada pasangan (suami dan isteri). Sesungguhnya Allah Maha Mengetahui lagi Maha Mengenal. 


\section{Implikasi dalam Butir-Butir Undang-Undang}

Setelah dijelaskan secukupnya tentang tujuan perkawinan dan diperkuat dengan makna tersirat dari pengertian dan status perkawinan, maka butir-butir batang tubuh Undang-Undang Perkawinan pun harus sejalan dengan dasar filosofis tersebut, dan menghindari butir-butiryang dapat mengarah pada kemungkinan lahir / munculnya butir yang mendiskriminasikan salah satu pasangan. Berikut sumbangan pemikiran terhadap draf Undang-Undang Perkawinan, dan lebih khusus telaah ditekankan pada tiga aspek; (1) poligami, (2) hubungan suami dan isteri, yang termasuk di dalamnya hak dan kewajiban, dan (3) perceraian. Sebab menurut hemat penulis, ketiga ha! ini menjadi problem sosial Indonesia yang sangat serius dan perlu mendapatkan perhatian khusus. Tujuannya adalah bagaimana caranya agar kelak lahir generasi yang berkualitas dan handal di masa depan.

Persoalan poligami, bahwa praktek poligami banyak disalahgunakan. Akibatnya sering melahirkan problem sosial, bukan saja bagi keluarga yang terlibat secara langsung dengan poligami seperti isteri dan anak-anaknya, tetapi juga sosial masyarakat secara luas. Banyak praktek poligami hanya bertanggung jawab melakukan aktifitas produksi, tetapi lari dari tanggung jawab untuk mencukupi kebutuhan dasar anak-anak dan isteri; sandang, pangan, papan dan pendidikan. Bahkan banyak pasangan poligami yang tidak mampu mencukupi kebutuhan sandang saja. Celakanya, suami yang melakukan tindakan ini tidak merasa bersalah. Akibatnya adalah anak yang lahir menjadi beban sosial. Karenanya perlu upaya untuk menghindari munculnya problem semacam ini. Salah satu upayanya adalah membuat aturan agar pelaku poligami benar-benar orang yang bertanggung jawab dan mampu. Karena itu, saya setuju dengan pembaruan isi Undang-Undang Perkawinan untuk dapat lebih menjamin kontekstualisasi kebolehan poligami. Bahwa poligami dilakukan harus benar-benar karena kebutuhan mendesak yang darurat bukan hanya pemenuhan kebutuhan biologis, dan pelakunya benarbenar bertanggung jawab menanggung segala resiko yang ditimbulkannya.

Maka saya mengusulkan isi draf, bahwa alasan poligami hanya kaiau isteri mendapat cacat badan atau penyakit yang tidak dapat disembuhkan. Sehingga alasan (1) tidak dapat menjalankan kewajiban sebagai isteri, dan (2) isteri tidak dapat melahirkan keturunan, tidak dapat menjadi alasan poligmi, kecuali usulan datang dari pihak isteri. Alasan pada ayat (1), bahwa isteri tidak dapat menjalankan kewajiban sebagai isteri, mempunyai makna yang sangat luas dan dapat menjadi dasar diskriminasi. Selanjutnya saya setuju dengan draf bahwa syarat poligami adalah (1) ada ijin dari isteri dan anak-anak yang sudah dewasa - sebelumnya (teks lama) hanya ijin isteri yang dibutuhkan, (2) suami menjadi tidak akan menceraikan isteri pertama, kecuali atas permintaan isteri pertama tersebut, dan bagi suami PNS isteri mendapat gaji $1 / 3$ dari gaji/pensiunan sampai bekas isteri menikah lagi, dan bagi yang bukan PNS isteri mendapat tunjangan hidup sesuai dengan kemampuan suami sampai menikah lagi. Alasan pentingnya ijin dari anak-anak yang sudah dewasa adalah, bahwa dalam banyak kasus ijin isteri diperoleh dengan jalan ancaman di belakang layar. Dengan adanya ijin dari anak yang sudah dewasa dapat terhindar dari praktek manipulasi ini.

Kaitannya dengan persoalan hubungan suami dan isteri, ada implikasi atau akibat 
negatif dari pemahaman, bahwa suami mempunyai hak memberikan pendidikan kepada isterinya. Pemahaman terhadap hak ini adalah, bahwa suami boleh memukul atau berlaku kasar kepada isterinya, dengan dalih memberikan pendidikan. Perilaku ini diyakini sejalan dengan ayat al-Qur'an surah al-Nisa' (4):34. Meskipun dalam banyak kasus sebanarnya suami yang salah, tetapi suami pula yang marah, seolah isteri melakukan kesalahan. Bahkan dalam banyak kasus suami berlaku kasar kepada isterinya. Praktek ini semakin mendapat justifikasi sebab dalam Undang-Undang Perkawinan Tahun 1974, pasal 31 ayat (3), disebutkan, suami adalah kepala rumah tangga dan isteri ibu rumah tangga. Lebihlebih lagi didukung dengan pasal 34 , yang menyebut, 'suami wajib melindungi isterinya ...' Sebab arti melindungi ini lebih ditekankan pada hak untuk memberikan pengajaran - dengan memukul dan memarahi- bukan kewajiban untuk mengayomi. Salah satu upaya menghindari munculnya kasus yang sama di masa depan, saya setuju pasal ini diperbarui menjadi; suami isteri wajib saling melindungi dan memberikan segala sesuatu keperluan untuk kebutuhan hidup keluarga dalam rangka membangun rumah tangga yang layak, sebagaimana yang tertulis dalam draf. Konsekuensinya, pasal 34 memang tidak dibutuhkan lagi, sebab secara substansial isinya sudah dicakup pasal 31 ayat (3) yang baru tadi, dan isinya lebih menjamin lahirnya pasangan yang egaletarian.

Masalah perceraian, adalah menjadi kepercayaan mayoritas masyarakat Indonesia bahwa cerai adalah mutlak suami. Akibatnya, suami boleh menceraikan isterinya kapan saja ia diinginkan. Lebih masalah lagi bahwa bekas isteri dan anakanak dari pasangan yang cerai ini hanya dibiarkan begitu saja oleh bekas suami dan bapak yang menceraikan. Kasus yang baru saja ditayangkan Indosiar hari Rabu, tanggal 2 April 2003, kasus di Nusa Tenggara Barat (NTB) adalah kasus nyata, ditambah dengan kasus-kasus lain di daerah-daerah lain. Dari kasus ini tampak, bahwa bekas suami dan bapak yang menceraikan tenang-tenang saja membiarkan bekas isteri dan anaknya hidup miskin dan sengsara tanpa mendapatkan kebutuhan pokok. Karena itu, masalah ini harus diupayakan jalan keluarnya. Di antaranya adalah membuat aturan yang menutup lahirnya masalah ini. Berangkat dari kasus-kasus ini saya mengusulkan agar isi pasal 38 lama diganti, bahwa putusnya perkawinan hanya karena: a. kematian, dan b. keputusan Pengadilan. Sehingga perceraian sepihak tidak ada lagi.

Sebagai catatan tambahan, perlu aturan tentang perceraian yang disebabkan oleh kenakalan isteri. Sebab banyak kasus perceraian yang disebabkan oleh kenakalan isteri, misainya selingkuh. Sayangnya suami yang menceraikan tetap harus membayar nafkah bekas isterinya, padahal isterinya yang menjadi sebab terjadinya perceraian.

Catatan tambahan lain, butir-butir Undang-Undang yang elok pun tidak maksimal dapat mencapai tujuan tanpa didukung oleh lembaga dan sumber daya manusia yang handal. Dalam kasus ini kualitas lembaga peradilan agama dan hakim-hakimnya memegang peranan penting dalam upaya maksimalisasi usaha tersebut. Karena itu, pemerintah periu secara serius dan berkesinambungan mengupayakan perbaikan lembaga peradilan dan mendidik para hakimnya menjadi hakim yang handal. Hakim di pengadilan agama menurut hemat penulis tidak cukup kalau hanya menguasai materi hukum perkawinan, tetapi lebih dari itu harus mengetahui secara mendalam substansi di balik materi hukum. 
Topik: Draf Undang-undang Perkawinan Indonesia..., Khoiruddin Nasution

Catatan berikutnya, pemerintah harus menanggung segala biaya administrasi yang berkaitan dengan pelaksanaan UndangUndang, seperti biaya pencatatan perkawinan. Sebab dengan demikian, orang tidak mempunyai alasan lagi untuk tidak mencatatkan perkawinan. Apa yang berlaki selama ini, bahwa orang yang tidak mampu boleh dibebaskan dari beban ini, adalah tidak efektik. Sebab tidak semua orang mau mengakui bahwa dia miskin. Lebih-lebih lagi proses untuk mendapatkan bebas tersebut malah lebih menjual harga diri orang tersebut. Ini hanya salah satu dari sekian biaya yang seharusnya ditanggung pemerintah demi efektifnya pemberlakuan Undang-Undang Perkawinan kelak.

\section{Penutup}

Dari pembahasan di atas tampak dengan jelas, bahwa untuk mencapai tujuan perkawinan yang sakinah, mawaddah dan rahmah bagi pasangan dan seluruh keluarga, dibutuhkan pembaruan pada sejumlah pasal Undang-Undang Perkawinan No. 1 Tahun 197.4. Itu saja tidak cukup tanpa ada usaha serius dan berkesinambungan dari pemerintah. Karena itu, usaha ini harus secepatnya ditempuh.

\section{Daftar Pustaka}

Abidin dan H. Aminuddin, 1999, Fiqh Munakahat. Bandung: Pustaka Setia.

Ghazâlî al-, Abû Hâmid Ihyyâ' , 1975. 'Ulum al-Dîn. Beirût: Dâr al-Fikr

Ibn Qudâmah, Mưwaffaqu al-Dîn Abî Muh\}ammad 'Abd Allâh bin Ahmad, al-Mughnî wa al-Sharh al-Kabîr, edisi 1. Beirût: Dâr al-Fikr, 1404/1984.

Jurjâwî al-, 1994, 'Aiî, Hikmatu al-Tasyri' wa Falsafatuh. Beirût: Dâr al-Fikr.

Kâsânî al-, al-Imâm 'Alâu al-Dîn Abî Bakar bin Mas'ûd, Kitâb Badâitu al-Sanâi'u fi Tartíb al-Shârâi', cet. 1. Beirût: Dâr al-Firk, 1417/1996.

Rahman, Fazlur, 1966, "The Controversy over The Muslim Family Law, "dalam Donald. E. Smith (ed.), South Asian Politics and Religion. Princeton: Princeton University Press.

Shihab, M. Quraish, 1996, Wawasan alQuran: Tafsir Maudhui iatas Pelbagai Persoalan Ummat. Bandung: Mizan.

Zuhailî al-, Wahbah, 1989,al-Fiqh al-Islâm wa Adillatuhu, cet. 3. Damaskus: Dâr al-Fikr. 